\title{
The Use of Non-financial Performance Measures: Does the Strength of Corporate Governance Matter?
}

\author{
Huiqi Gan \\ University of Massachusetts Lowell \\ Melloney C. Simerly \\ Western Kentucky University
}

This study investigates whether strong board oversight is influential in firms' choice of incorporating non-financial performance measures (NFPM) in executive compensation. We find that more independent boards, boards with inconsequential entrenchment, larger boards, boards with a higher percentage of reputable directors and gender diverse boards, favor the use of NFPM. These findings suggest the importance of board strength in influencing firms' decision of using NFPM, and that corporate governance strength should be a priority for maintaining an optimal contracting environment for executives.

Keywords: Non-Financial Performance Measure, Board Oversight, Board Characteristics

\section{INTRODUCTION}

This study examines whether the strength of board oversight influences the choice of using nonfinancial performance measures (NFPM) for executive compensation. NFPM such as productivity, customer satisfaction, employee satisfaction, market share percentage, strategic goals, quality measures and operational efficiency, have been identified as valuable because they contribute incremental information about managerial behavior, provide more timely feedback, and mitigate the inherent risk as well as noise in financial measures (e.g., Lambert \& Larcker, 1987; Bruns \& McKinnon, 1993; Feltham \& Xie, 1994; Bushman et al., 1996; Hemmer, 1996; Davila \& Venkatachalam, 2004). This suggests that NFPM can contribute to reducing information asymmetry and create a more efficient contracting environment. However, NFPM are prone to managerial manipulation due to the absence of public verification (e.g., Eccles \& Mavrinac, 1995; Ittner et al., 1997). Consequently, increased board oversight may be necessary to achieving an optimal contracting environment. Therefore, whether the strength of board monitoring plays a role in the decision to use NFPM for CEO compensation is a compelling research question.

We argue that NFPM are more likely to be adopted by firms with board structure characteristics indicative of strong corporate governance. These include board independence, board size, inconsequential entrenchment, reputable directors and gender diversity. The BOD (board of directors) bears the responsibility of designing executive compensation incentives that motivate CEOs to act in the best interest of shareholders (Fama \& Jensen, 1983; Jensen, 1993; Core et al., 1999; Cyert et al., 2002). 
Additionally, the board fulfil an oversight function to ensure the proper implementation of performance measures related to compensation (e.g., Lambert et al., 1993; Boyd, 1994; Mehran, 1995; Core et al., 1999; Ryan \& Wiggins, 2001). NFPM can provide important contracting benefits unless they are unscrupulously manipulated (Eccles \& Mavrinac, 1995; Ittner et al., 1997). Therefore, an optimal contracting environment requires the presence of strong board monitoring to ensure that the benefits of adopting NFPM are realized.

Utilizing hand collected data regarding firms' use of NFPM for CEO compensation, we find some evidence that independent boards promote the use of NFPM. Additionally, we show that firms with higher levels of inside director ownership value do not favor the use of NFPM, supporting the argument that board entrenchment impedes the use of NFPM. We also document significant findings that larger boards, boards with reputable directors, and boards that are more gender diverse (i.e. boards that include female directors) favor the use of NFPM. Our robustness tests include both the instrumental variable approach and propensity score matching.

This study makes the following contributions. The extant literature has established that firm characteristics, such as strategy, length of the product development cycle, length of the product life cycle, level of noise in financial measures, and financial performance, are key factors related to the use of NFPM (e.g., Ittner et al., 1997; Ittner \& Larcker, 1998a; 1998b; Said et al., 2003; HassabElnaby et al., 2005). Building on this stream of literature, our study indicates that board strength is also a relevant mechanism influencing the choice of using NFPM for CEO compensation, thereby, increasing the efficiency of the contracting environment. We show that more independent boards, larger boards as well as boards with a higher percentage of reputable directors and female directors promote the use of NFPM. On the other hand, entrenched boards, indicated by high levels of inside director ownership value, are a deterrent for the use of NFPM. These findings promote a more long-term perspective for managerial decision making (Kaplan \& Atkinson, 1998).

The remainder of this paper is organized as follows. In Section 2, we discuss previous literature and develop our hypotheses. We describe our research design in Section 3. Our results and additional analyses are presented in Sections 4 and 5. The conclusions of the study are discussed in Section 6.

\section{LITERATURE REVIEW AND HYPOTHESIS DEVELOPMENT}

\section{Non-financial Performance Measures in Executive Compensation Contracts}

Research concerning the nature and effects of NFPM in executive contracts draws two main conclusions: 1) NFPM have incremental value in reducing information asymmetry, thereby creating a more efficient contracting environment (e.g., Feltham \& Xie, 1994; Amir \& Lev, 1996; Hemmer, 1996; Ittner et al., 1997; Srinivasan et al., 2004; Davila \& Venkatachalam, 2004), and 2) NFPM lead to better strategic alignment that can create conditions for improved future firm performance and higher firm value (e.g., Kaplan \& Johnson, 1987; Lamber \& Larcker, 1987; Hauser et al., 1994; Kaplan \& Norton, 1996; Ittner \& Larcker, 1998a; 1998b; Banker et al., 2000; Said et al., 2003; Schiehll \& Bellavance, 2009). Following the informativeness principle, the use of NFPM contributes to the monitoring effectiveness of agent efforts and can mitigate the moral hazard problem (Holmstrom, 1979). Moreover, Feltham \& Xie (1994) assert that NFPM are useful in evaluating agent performance because NFPM can increase the robustness of noisy financial measures.

Traditional financial measures, such as earnings and returns, tend to capture the effects of historical and current activities. Conversely, NFPM reveal contemporaneous information regarding managerial actions that continue to have positive effects in the future, creating long-term benefits (Kaplan \& Norton, 1996). Several studies document that NFPM are significantly and positively related to improved current and future firm performance (e.g., Hauser et al., 1994; Ittner \& Larcker 1998a; 1998b; Banker et al., 2000; Nagar \& Rajan, 2001; Said et al., 2003; Sedatole, 2003; Banker and Mashruwala, 2007). For instance, Banker et al. (2000) show that customer satisfaction redirects the effort of managers to engender a more long-term perspective and is significantly related to future financial performance in the hospitality industry. Nagar \& Rajan (2001) and Sedatole (2003) document that product quality measures are 
positively associated with future sales and can predict future financial performance. Finally, Banker \& Mashruwala (2007) demonstrate that both employee satisfaction and customer satisfaction are related to future profits for firms in highly competitive environments. Thus, the extant literature is clear that the use of NFPM in the design of CEO compensation contracting not only mitigates the agency dilemma through increased information transparency, but also creates conditions for improved firm and operational performance. However, prior literature indicates that NFPM may be more prone to managerial manipulation.

In a survey of analysts and investors, Eccles \& Mavrinac (1995) find that their respondents desire nonfinancial performance information but prefer to get the information from independent sources. Analysts are suspicious of NFPM obtained directly from executives. They believe that much of this information is manipulated to satisfy managerial self-interest because it is not validated by an independent auditing process. Since, NFPM is more difficult for external stakeholders to verify (Eccles \& Mavrinac, 1995; Ittner et al., 1997), the role of the BOD is an important factor in producing non-biased NFPM information and thus achieving the many benefits of using NFPM.

\section{Board Oversight and the Use of NFPM in CEO Compensation Contracts}

Due to the agency dilemma, managers may not always act in the best interest of shareholders. Such agency problems can be alleviated by providing appropriate monitoring and incentives that align the interests for both parties (e.g., Jensen \& Meckling, 1976; Kaplan, 1982; Fama \& Jensen, 1983; Baysinger \& Butler, 1985; Cyert et al., 2002). Thus, performance measurement systems and additional corporate governance mechanisms coalesce to reduce agency costs. The board of directors bears the responsibility for designing effective compensation schemes that motivate executives to act in the best interest of shareholders and monitor management to ensure compensation policies have been appropriately implemented (e.g., Lambert et al., 1993; Boyd, 1994; Mehran, 1995; Core et al., 1999; Ryan \& Wiggins, 2001). NFPM should help to create a more efficient contracting environment by providing a managerial incentive to align actions with firm strategy and make decisions based on a more long-term perspective. However, if managers manipulate NFPM to meet their own self-interests rather than shareholder interests, an optimal contracting environment will not be achieved. Therefore, we propose that strong corporate governance mitigates this issue, resulting in a more efficient contracting environment.

Prior research highlights several BOD characteristics that are important for ensuring strong corporate governance. These include board independence, inconsequential entrenchment, board size, director reputation and gender diversity. Independent boards have little incentive to conspire with managers in exploiting firm and shareholder value perfidiously (Fama and Jensen, 1983). Consequently, the inclusion of outside directors can enhance the board's capability for effectively monitoring agency settings where ownership is separate from control (Weisbach, 1988; Beasley, 1996).

Whether a BOD is entrenched is also an important factor pertaining to strength of corporate governance. Directors can become entrenched in response to high levels of equity-based incentives (Morck et al., 1988) or as a result of CEO/Chair duality (i.e. CEO also serves as chairperson of the BOD). Prior studies suggest that entrenched boards, evidenced by high levels of director ownership and $\mathrm{CEO} /$ Chairperson duality, are ineffective for promoting BOD monitoring activities and can lead to failures in making optimal decisions that promote shareholder interests (e.g., Fama \& French, 1983; Shleifer \& Vishny, 1989; McConnell \& Servaes, 1990; Hermalin \& Weisbach, 1991). We predict that firms with a high level of director equity ownership and firms with CEO/Chairperson duality, will be less likely to adopt NFPM for CEO compensation.

Core et al. (1999) find that increasing board size is positively associated with CEO compensation, implying that larger boards are less effective in monitoring levels of CEO pay. Consistent with this evidence, Yermack (1996) finds that smaller boards are more efficient and lead to increased market value. However, larger boards are better able to influence their environment to meet firm needs and have more resources at their disposal (Haveman, 1993). In addition, NFPM can increase the efficiency of board monitoring and as such, may be relied on more frequently by larger boards to fill a need for increasing 
BOD effectiveness (Holmstrom, 1979). Thus, the research is unclear as to how board size is related to the use of NFPM, making the association an interesting question.

Director reputation is also an indicator for corporate governance strength. Directors with a strong positive reputation in relation to colleagues will hesitate to side with the CEO concerning higher levels of pay. This is true for both inside and outside directors. Inside directors will refrain from siding with the CEO because they may be successors to the current CEO and wish to avoid alienating outside directors (Mizruchi, 1983). Outside directors have incentive to maintain a reputation of being objective to increase the chances of being appointed to other BODs to advance their career (Baysinger \& Hoskisson, 1990). Directors use their involvement with firms to provide evidence to the market that they are experts in decision control (Fama \& Jensen, 1983). Reputation, positive or negative, has consequences in the job market. Fich \& Shivdasani (2006) document that directors affiliated with firms being sued for fraud are likely to lose directorships on other BODs. As such, we posit that directors holding multiple directorships are more likely to have favorable reputations and be associated with the use of NFPM.

Finally, gender diversity within the board structure can strengthen corporate governance. BODs including female directors can improve the informativeness of stock prices and act as a substitute for weak corporate governance (Gul et al., 2011). Female CEOs are associated with firms that have lower leverage and less volatile earnings (Faccio et al., 2016). Additionally, gender diverse boards demonstrate more restraint over earnings management practices (Srinidhi et al., 2011; Arun et al., 2015). Adams \& Ferreira (2009) find that female directors tend to be more involved in monitoring activities. This leads to a corporate governance structure that is more effective in ensuring managers are making decisions that increase shareholder value, thereby increasing the strength of corporate governance.

In sum, prior studies substantiate that there are several indicators for strong corporate governance that provide more effective oversight regarding managerial practices and can ensure a more efficient contracting environment. Given that NFPM are prone to manipulation but when used in conjunction with a strong governance structure can provide numerous benefits for reducing agency costs, we propose that the strength of corporate governance is positively associated with the likelihood of using NFPM.

H1: The use of NFPM is positively associated with stronger corporate governance.

\section{RESEARCH DESIGN}

\section{Data and Sample Selection}

Our sample consists of firms listed on the Standard and Poor 500 index (S\&P 500) at least once from 1991-2012. ${ }^{1}$ The data pertaining to BOD information and financial characteristics were obtained from the RiskMetrics and Compustat databases. NFPM information was hand collected by reviewing proxy statement disclosures listed on the U.S. Securities and Exchange Commission Electronic Data-Gathering, Analysis, and Retrieval (EDGAR) database for the years 2000-2014. We obtained 5,530 firm-year observations for the final sample after deleting observations with missing values for the required variables.

\section{Dependent Variables}

We hand collected NFPM information by reading S\&P 500 firm proxy statement disclosures listed on the U.S. Securities and Exchange Commission EDGAR database. Following Ittner et al. (1997), we identified firms as using NFPM by searching for the keywords: non-financial, nonfinancial, customer satisfaction, employee satisfaction, employee morale, employee motivation, quality process, improvement, individual objectives, reengineering, new product development, diversity, market share, productivity, efficiency, safety, innovation, operational measure, operational performance, strategic objectives, individual performance, and individual goals. Firms that use both financial and NFPM were coded as one ${ }^{2}$; firms that use only financial performance measures were coded as zero. We employ this binary measure labelled NFPM_CODE as our first dependent variable. In addition, firms introducing NFPM may reduce the weight placed on financial measures for performance compensation and assign, or 
increase the weight placed on non-financial measures (e.g., Hemmer, 1996; Kaplan \& Atkinson, 1998). The weight placed on a performance measure, signals the importance of the incentive (Ittner et al., 1997; O'Connell \& O'Sullivan, 2014). Further, Ittner et al. (2003) provide evidence that the weight placed on a non-financial measure reflects management's subjective interpretation for the value of the measure. Following other studies that investigate the use of NFPM (e.g., Ittner et al., 1997; Said et al., 2003; HassabElnaby et al., 2005), we also use the weight placed on NFPM as an alternative dependent variable. We collected the information, if disclosed, for the weights assigned to NFPM (NFPM_WEIGHT). Finally, to test the robustness of our study, we use COUNTNFPM, a categorical variable which measures the number of NFPM used by a firm in a given year, as a third dependent variable.

\section{Independent Variables of Interest}

To measure the strength of board oversight, we employ six variables to proxy for various board characteristics. Specifically, our independent variables of interest include: proportion of independent directors (INDPT_PCNT), value of ownership held by inside directors (INS_SHARES), CEO/Chairman duality (CEO/Chairman), board size (BOD_SIZE), percentage of reputed directors (REPUTED_DIR), and percentage of female directors (FEMALE_PCNT).

\section{Empirical Models}

Given that compensation contract decisions are made at the beginning of the year, we employ predicted models by lagging the independent variables to test the association between board characteristics and the use of NFPM. When testing the model with different dependent variables, we utilize probit regression when the dependent variable is the likelihood of using NFPM (NFPM_CODE), OLS regression when the dependent variable is the weights of NFPM (NFPM WEIGHT) and ordered probit regression when the dependent variable is the number of NFPM used (COUNTNFM). We control for year effects and industry effects as well as report robust standard errors that are corrected for heteroskedasticity. We estimate the following model to investigate the association between board characteristics and the use of NFPM:

$$
\begin{aligned}
& \mathrm{NFPM}_{\mathrm{i}, \mathrm{t}}=\beta_{0}+\beta_{1} \text { INDPT_PCNT }_{\mathrm{i}, \mathrm{t}-1}+\beta_{2} \mathrm{INS}_{-} \mathrm{SHARES}_{\mathrm{i}, \mathrm{t}-1}+\beta_{3} \mathrm{CEO} / \mathrm{CHAIR}_{\mathrm{i}, \mathrm{t}-1}+\beta_{4} \mathrm{BOD}_{-} \mathrm{SIZE}_{\mathrm{i}, \mathrm{t}-1} \\
& +\beta_{5} \text { REPUTED_DIR }_{\mathrm{i}, \mathrm{t}-1}+\beta_{6} \text { FEMALE_PCNT }_{\mathrm{i}, \mathrm{t}-1}+\beta_{7} \mathrm{SIZE}_{\mathrm{i}, \mathrm{t}-1}+\beta_{8} \overline{\mathrm{ROA}}_{\mathrm{i}, \mathrm{t}-1-1}+\beta_{9} \mathrm{LEV}_{\mathrm{i}, \mathrm{t}-1} \\
& +\beta_{10} \text { DIST }_{\mathrm{i}, \mathrm{t}-1 \text { thru t-5}}+\beta_{11} \overline{\mathrm{STRATEGY}}_{\mathrm{i}, \mathrm{t}-1 \text { thru t-5}}+\bar{\beta}_{12} \text { MNOISE }_{\mathrm{i}, \mathrm{t}-1 \text { thru t-5}}+\beta_{13} \mathrm{QUALITY}_{\mathrm{i}, \mathrm{t}} \\
& +\beta_{14} \text { DCYCLE }_{i, t}+\beta_{15} L_{C Y C L E},+ \text { INDUSTRY\&YEAR }+e_{i, t,}
\end{aligned}
$$

where

NFPM = NFPM_CODE, an indicator variable that takes the value of one if the firm uses NFPM in CEO compensation contracts, and zero otherwise; or NFPM_WEIGHT, a continuous variable indicating the weight placed on NFPM in compensation contracts; or COUNTNFPM, the number of NFPM used by a firm in a given year;

INDPT_PCNT $=$ the percentage of independent board directors;

INS_SHARES = the natural logarithm for the value of shares held by inside board members;

$\mathrm{CEO} / \mathrm{CHAIR}=$ an indicator variable that takes the value of one if a CEO is also the Chairman of the board, and zero otherwise;

BOD_SIZE $=$ the number of board of directors on a corporate board;

REPUTED_DIR = percentage of board of directors who hold more than one seat on other major company boards;

FEMALE_PCNT $=$ percentage of female directors on a board;

$\mathrm{SIZE}=$ the natural logarithm of total assets at year $\mathrm{t}-1$;

$\mathrm{ROA}=$ net income before extraordinary items and discontinued operations, deflated by lagged total assets at year $\mathrm{t}-1$;

$\mathrm{LEV}=$ total liabilities divided by total assets at year $\mathrm{t}-1$;

DIST $=$ bankruptcy probability, computed for each of the preceding five years using Ohlson's (1980) model; 
STRATEGY = the composite score for organizational strategy using three variables: 1) ratio of research and development to sales, 2) market-to-book ratio, and 3) ratio of number of employees to sales averaged over previous five years;

MNOISE $=$ a composite measure of Fisher z-scores for the correlations between return on assets, return on equity, and return on sales, with stock market returns for the five years prior to each proxy date;

QUALITY = an indicator variable coded as one if a firm is a quality award winner, and zero otherwise;

DCYCLE = an indicator variable coded as one if a firm is classified as having long-term product development cycle, and zero otherwise;

LCYCLE = an indicator variable coded as one if a firm is classified as having long-term product life cycle, and zero otherwise;

INDUSTRY = industry indicators using the first digit of the SIC code; and

$\mathrm{YEAR}=$ an indicator variable for each year.

Using a lagged model design can mitigate the endogeneity problem for our research context, to certain extent. However, we further control for endogeneity by conducting robustness tests using an instrumental variable approach to test the association between board characteristics and the use of NFPM. ${ }^{3}$ Following prior studies that use past values of governance and performance as instruments for predicting future governance effects, we use the two-year lagged form of BOD characteristics and a oneyear lagged variable for free cash flow as instruments for the independent variables of interest (e.g., Hermalin \& Weisbach, 1991; Guest, 2009). ${ }^{4}$ Relevance and validity tests were also conducted for the two instruments. ${ }^{5}$

\section{Control Variables}

Following prior studies (Ittner et al., 1997; Said et al., 2003; and HassabElnaby et al., 2005), we include a control variable in the models for the noise inherent in financial measures. This measure, MNOISE, is a composite measure constructed by using Fisher z-scores for the correlations between return on assets, return on equity, and return on sales, with stock market returns for the five years prior to each proxy date. In addition, firms experiencing poor performance are less likely to incorporate NFPM for CEO pay (Ittner et al., 1997; HassabElnaby et al., 2005). We therefore include a control for firm financial distress (DIST). This variable is constructed for the five years prior to the proxy statement date using Ohlson's (1980) model. HassabElnaby et al. (2005) provide evidence that firms' prior financial performance is a key factor for the use and retention of NFPM. As such, we control for performance by incorporating return on assets (ROA) for the prior year. Additionally, prospector firms, firms with strong quality initiatives, and firms with longer product development and life cycles are more likely to adopt NFPM (e.g., Ittner et al., 1997; Said et al., 2003; HassabElnaby et al., 2005). Hence, we include additional control variables such as a measure of firm strategy for the previous five years (STRATEGY) and an indicator variable for quality award winners (QUALITY). We control for firm product development and life cycles by using industry fixed effects. Finally, following Said et al. (2003) and HassabElnaby et al. (2005) we also control for firm size (SIZE) and leverage (LEV).

\section{RESULTS}

\section{Descriptive Statistics and Univariate Results}

We began with 14,238 observations of hand collected NFPM data for the years $2000-2014$. We then merged these data with the financial variable data obtained from COMPUSTAT and the director information retrieved from the Risk Metrics database. Our initial sample contained 7,604 firm-year observations. Missing data account for the exclusion of 1,521 firm year observations and 88 observations were dropped due to the absence of variability for the dependent variable at the industry level (based on a two-digit SIC code). Thus, our final sample consists of 5,995 firm-year observations. In Table 1, we present the sample distribution by year and by two-digit SIC. 
TABLE 1

SAMPLE DISTRIBUTION

Panel A: By Year

\begin{tabular}{ccc} 
Year & & \# of Obs. \\
\cline { 1 - 1 } 2000 & & 422 \\
2001 & & 443 \\
2002 & & 414 \\
2003 & & 421 \\
2004 & & 422 \\
2005 & & 404 \\
2006 & & 394 \\
2007 & & 324 \\
2008 & & 329 \\
2009 & & 407 \\
2010 & & 411 \\
2011 & 397 \\
2012 & & 409 \\
2013 & 397 \\
2014 & & 401 \\
Total & 5,995 \\
\hline
\end{tabular}

\begin{tabular}{c} 
\% of Sample \\
\hline 7.04 \\
7.39 \\
6.91 \\
7.02 \\
7.04 \\
6.74 \\
6.57 \\
5.40 \\
5.49 \\
6.79 \\
6.86 \\
6.62 \\
6.82 \\
6.62 \\
6.69 \\
\hline 100.00 \\
\hline \hline
\end{tabular}

\begin{tabular}{c} 
Cumulative Percent \\
\hline 7.04 \\
14.43 \\
21.33 \\
28.36 \\
35.40 \\
42.14 \\
48.71 \\
54.11 \\
59.60 \\
66.39 \\
73.24 \\
79.87 \\
86.69 \\
93.31 \\
100.00 \\
\hline
\end{tabular}

Panel B: By Industry

\begin{tabular}{lcccc} 
Industry & $\begin{array}{c}\text { 2-Digit } \\
\text { SIC }\end{array}$ & $\begin{array}{c}\text { \# of } \\
\text { Obs. }\end{array}$ & $\begin{array}{c}\text { \% of } \\
\text { Sample }\end{array}$ & $\begin{array}{c}\text { Cumulative } \\
\text { Percent }\end{array}$ \\
\hline Oil and Gas & 13 & 336 & 5.60 & 5.60 \\
Food, Beverage & 20 & 299 & 4.99 & 10.59 \\
Paper and Allied Products & 26 & 107 & 1.78 & 12.38 \\
Printing and Publishing & 27 & 94 & 1.57 & 13.94 \\
Chemicals and Allied Products & 28 & 553 & 9.22 & 23.17 \\
Petroleum & 29 & 66 & 1.10 & 24.27 \\
Rubber & 30 & 64 & 1.07 & 25.34 \\
Primary Metal Industries & 33 & 97 & 1.62 & 26.96 \\
Fabricated Metal Products & 34 & 80 & 1.33 & 28.29 \\
Industrial Machinery \& Computer & 35 & 469 & 7.82 & 36.11 \\
Equipment & 36 & 474 & 7.91 & 44.02 \\
Electronic and Other Electric Equipment & 37 & 149 & 2.49 & 46.51 \\
Transportation Equipment & 38 & 326 & 5.44 & 51.94 \\
Instruments and Related Products & 40 & 54 & 0.90 & 52.84 \\
Railroad Transportation & 48 & 167 & 2.79 & 55.63 \\
Communication & 49 & 554 & 9.24 & 64.87 \\
Electric, Gas, and Sanitary Services & 50 & 63 & 1.05 & 65.92 \\
Wholesale-Durable Goods & 51 & 68 & 1.13 & 67.06 \\
Wholesale-Non-Durable Goods & 53 & 147 & 2.45 & 69.51 \\
General Merchandise Store & 54 & 65 & 1.08 & 70.59 \\
Food Stores & 55 & 65 & 1.08 & 71.68 \\
Auto Dealers, Gas Stations & & & &
\end{tabular}




\begin{tabular}{lcccc} 
Apparel and Accessory Stores & 56 & 127 & 2.12 & 73.79 \\
Eating and Drinking & 58 & 80 & 1.33 & 75.13 \\
Miscellaneous Retail & 59 & 100 & 1.67 & 76.80 \\
Security And Commodity Brokers, etc. & 62 & 53 & 0.88 & 77.68 \\
Insurance Carriers & 63 & 54 & 0.90 & 78.58 \\
Business Services & 73 & 568 & 9.47 & 88.06 \\
Health Services & 80 & 68 & 1.13 & 89.19 \\
Other Industries $^{1}$ & & 648 & 10.81 & 100.00 \\
\hline Total & 5,995
\end{tabular}

As shown in Panel A of Table 1, in general, the sample is evenly distributed across all years. In addition, in Panel B of Table 1, we show the industry with highest frequency in our sample is Business Services (9.47 percent, SIC code 73), followed by Electric, Gas, and Sanitary Services (9.24 percent, SIC code 49) and Chemical and Allied Products (9.22 percent, SIC code 28).

The descriptive statistics for the final sample are contained in Table 2. In Panel A of Table 2, we report the descriptive statistics for the full sample. In Panels B, C, E, F, and G of Table 2, we divide the full sample into two groups using the median proportion of independent directors, the median of inside director ownership, the median board size, the median percentage of reputed directors, and the median percentage of female directors. In Panel D of Table 2, we divided the sample into two groups, one with $\mathrm{CEO} /$ Chairman duality and one without this characteristic. Based on these segregations, we report the mean and the median frequencies for the use of NFPM, the weights placed on NFPM, and the number of NFPM used and test for differences. 


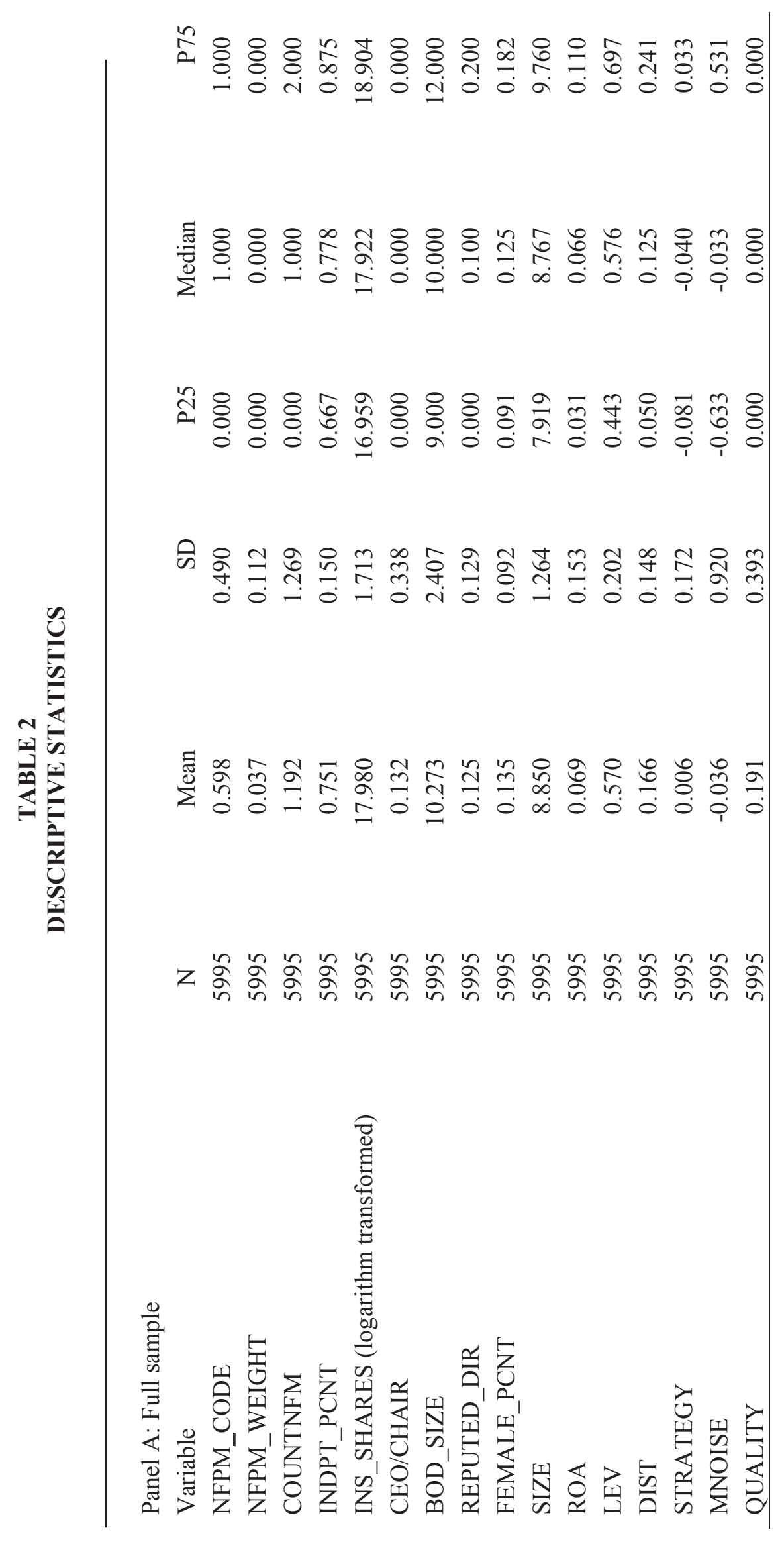




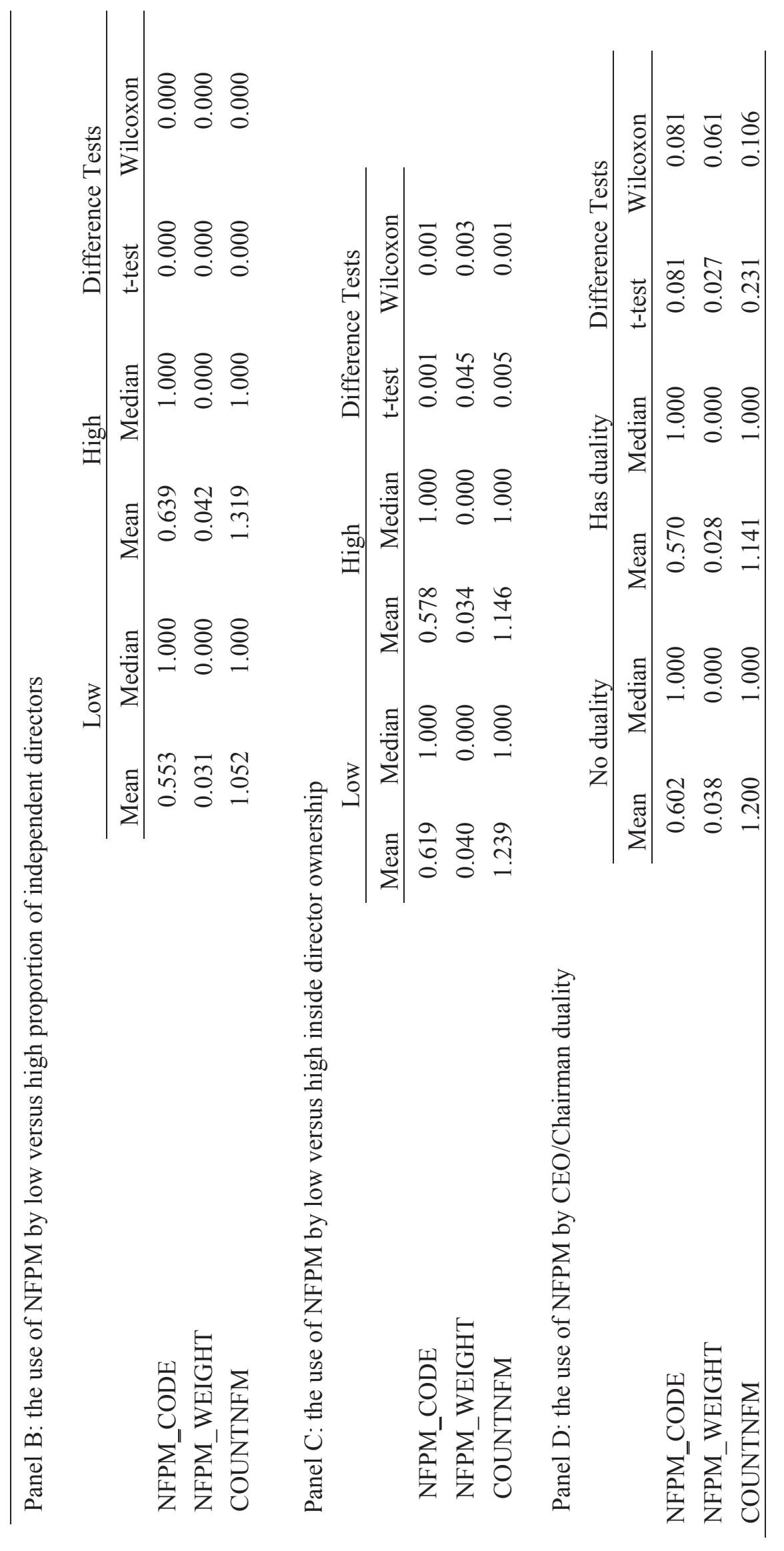

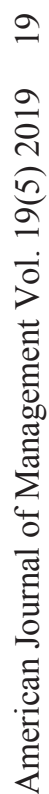




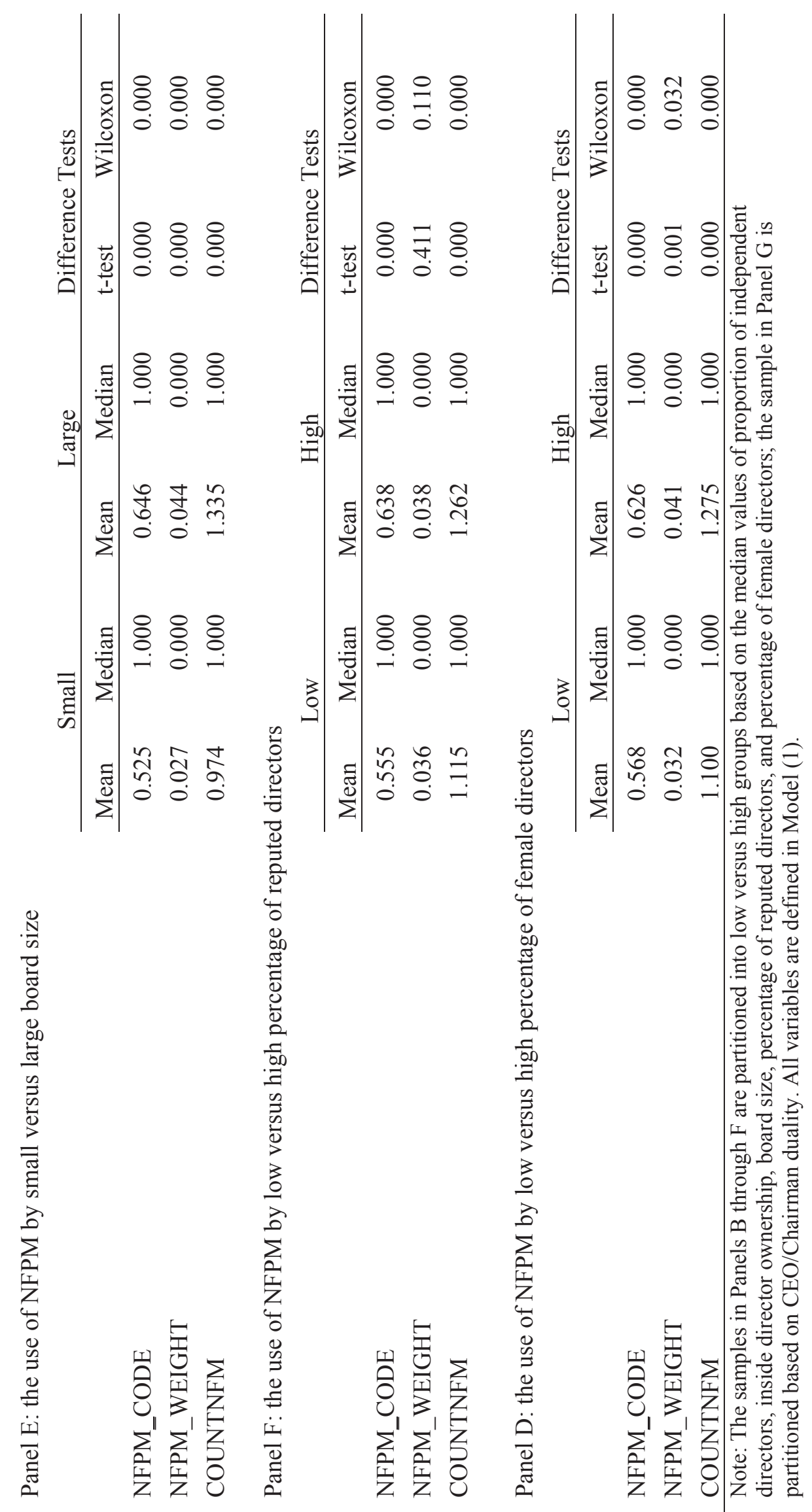

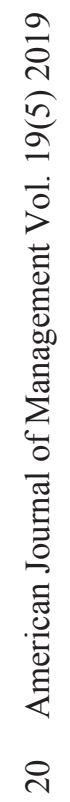


In Panel A of Table 2, we document that more than half of the sample use NFPM in CEO compensation (mean 0.598), the average weight of NFPM is 3.7 percent, and the number of NFPM used has an average greater than 1. Regarding the independent variables of interest, the mean percentage of independent directors is 75.1 and the median is 77.8 percent. The mean for inside director ownership is 17.980 with a median of 17.922. Approximately 13.2 percent of firm-year observations have $\mathrm{CEO}$ /Chairman duality. Average board size is about 10. Mean and median percentage of reputed directors are 12.5 percent and 10.0 percent, respectively. On average, 13.5 percent of board of directors are female. Turning to the control variables, the average size of firms in our sample is 8.884 with a median size of 8.892 noted. Average return on assets is 0.069 and the firms in our sample have an average debt to asset ratio of 0.579 . Moreover, 19.7 percent of the firms are quality award winners, 33.7 percent have a long product development cycles, and 66.1 percent of the sample have long product life cycles.

Panel B of Table 2 reveals that firms with a higher proportion of independent directors are more likely to use NFPM, place more weight on NFPM, and more frequently use NFPM in CEO compensation contracts. In contrast, Panel $\mathrm{C}$ indicates that firms with a higher inside director ownership are less likely to use NFPM, place less weight on NFPM, and use fewer NFPM. In Panel D, we see that firms without $\mathrm{CEO}$ /Chairman duality tend to be more likely to use NFPM and place more weight on NFPM. Panel E shows that firms with larger boards are more likely to use NFPM, assign higher weights, and use more NFPM. Panel F shows that firms having more reputed directors are more likely to use and more frequently employ NFPM. Finally, Panel G indicates that firms with higher percentage of female directors favor the use of NFPM.

Table 3 shows the Pearson correlations between the dependent variables, the independent variables of interest, and the controls. NFPM_CODE is positively correlated with the proportion of independent directors, board size, percentage of reputable directors, percentage of female directors, and negatively correlated with inside director ownership as well as CEO/Chairman duality. Using NFPM_WEIGHT produces similar results, with the exception of a negative correlation of NFPM_WEIGHT with percentage of reputed directors. In addition, table 3 documents that COUNTNFM, the number of NFPM used, is positively correlated with proportion of independent directors, board size, and percentage of female directors, and negatively correlated with inside director ownership.

Turning to the control variables, the dependent variables positively correlated with firm size, ROA, leverage, and quality award winners, but negatively correlated with strategy and financial noise. 


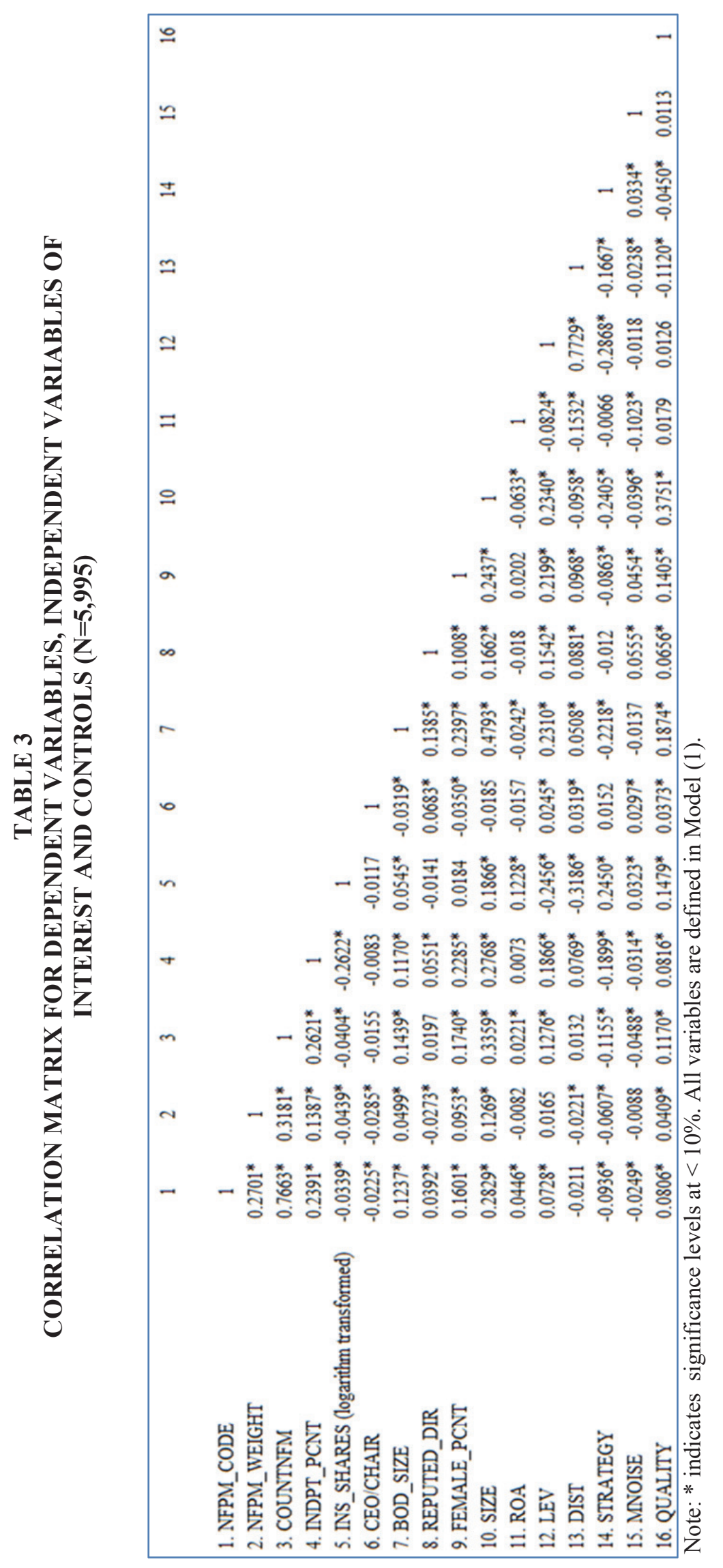

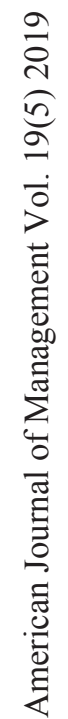

ส 


\section{Multivariate Regression Results}

We predict that the use of NFPM is positively associated with stronger corporate governance. The results of testing this assertion using Model (1) are reported in Table 4.

TABLE 4

MULTIVARIATE REGRESSION RESULTS (N = 5995)

\begin{tabular}{|c|c|c|c|}
\hline & $\begin{array}{c}(1) \\
\text { P(NFPM_CODE) } \\
\text { Coefficient } \\
\text { (Z-stat) }\end{array}$ & $\begin{array}{c}(2) \\
\text { NFPM_WEIGHT } \\
\text { Coefficient } \\
\text { (t-stat) }\end{array}$ & $\begin{array}{c}(3) \\
\text { COUNTNFPM } \\
\text { Coefficient } \\
\text { (Z-stat) }\end{array}$ \\
\hline INDPT_PCNT & $\begin{array}{l}0.065 \\
(0.42)\end{array}$ & $\begin{array}{r}0.009 \\
(0.89)\end{array}$ & $\begin{array}{c}0.196 \\
(1.53)\end{array}$ \\
\hline INS_SHARES & $\begin{array}{l}-0.069 * * * \\
(-5.06)\end{array}$ & $\begin{array}{l}-0.004 * * * \\
(-4.46)\end{array}$ & $\begin{array}{l}-0.046^{* * *} \\
(-4.21)\end{array}$ \\
\hline CEO/CHAIR & $\begin{array}{c}0.072 \\
(1.35)\end{array}$ & $\begin{array}{r}0.001 \\
(0.23)\end{array}$ & $\begin{array}{l}0.095^{* *} \\
(2.14)\end{array}$ \\
\hline BOD_SIZE & $\begin{array}{l}0.027 * * * \\
(2.78)\end{array}$ & $\begin{array}{r}-0.000 \\
(-0.24)\end{array}$ & $\begin{array}{l}0.017^{* *} \\
(2.18)\end{array}$ \\
\hline REPUTED_DIR & $\begin{array}{l}0.552^{* * * *} \\
(3.61)\end{array}$ & $\begin{array}{r}-0.013 \\
(-1.17)\end{array}$ & $\begin{array}{l}0.319^{* *} \\
(2.50)\end{array}$ \\
\hline FEMALE_PCNT & $\begin{array}{l}1.282^{* * * *} \\
(5.26)\end{array}$ & $\begin{array}{l}0.060^{* * * *} \\
(3.37)\end{array}$ & $\begin{array}{l}1.108^{* * * *} \\
(5.98)\end{array}$ \\
\hline SIZE & $\begin{array}{l}0.200^{* * *} \\
(8.00)\end{array}$ & $\begin{array}{l}0.005^{* * *} \\
(2.64)\end{array}$ & $\begin{array}{l}0.201^{* * *} \\
(10.09)\end{array}$ \\
\hline $\mathrm{ROA}$ & $\begin{array}{l}1.269^{* * *} \\
(5.53)\end{array}$ & $\begin{array}{r}-0.000 \\
(-0.07)\end{array}$ & $\begin{array}{l}0.963^{* * *} \\
(5.21)\end{array}$ \\
\hline LEV & $\begin{array}{l}-0.236 \\
(-1.37)\end{array}$ & $\begin{array}{l}-0.027 * * \\
(-2.13)\end{array}$ & $\begin{array}{r}0.073 \\
(0.53)\end{array}$ \\
\hline DIST & $\begin{array}{l}0.417^{*} \\
(1.80)\end{array}$ & $\begin{array}{r}0.010 \\
(0.59)\end{array}$ & $\begin{array}{l}0.407 * * \\
(2.07)\end{array}$ \\
\hline STRATEGY & $\begin{array}{r}0.082 \\
(0.74)\end{array}$ & $\begin{array}{l}-0.012^{* *} \\
(-2.21)\end{array}$ & $\begin{array}{c}0.004 \\
(0.04)\end{array}$ \\
\hline MNOISE & $\begin{array}{l}0.010 \\
(0.49)\end{array}$ & $\begin{array}{r}0.001 \\
(0.35)\end{array}$ & $\begin{array}{r}-0.012 \\
(-0.75)\end{array}$ \\
\hline QUALITY & $\begin{array}{r}0.055 \\
(1.02)\end{array}$ & $\begin{array}{l}0.012 * * * \\
(2.65)\end{array}$ & $\begin{array}{l}0.090 * * \\
(2.07)\end{array}$ \\
\hline CONSTANT & $\begin{array}{l}-1.118^{* * * *} \\
(-2.96)\end{array}$ & $\begin{array}{l}0.077 * * * \\
(2.73)\end{array}$ & \\
\hline CONSTANT_1 & & & $\begin{array}{l}1.738^{* * * *} \\
(5.76)\end{array}$ \\
\hline CONSTANT_2 & & & $\begin{array}{l}2.550^{* * * *} \\
(8.43)\end{array}$ \\
\hline CONSTANT_3 & & & $\begin{array}{l}3.172 * * * \\
(10.45)\end{array}$ \\
\hline CONSTANT_4 & & & $\begin{array}{l}3.768^{* * * *} \\
(12.41)\end{array}$ \\
\hline Industry fixed effect & Yes & Yes & Yes \\
\hline Year fixed effect & Yes & Yes & Yes \\
\hline Pseudo $\mathrm{R}^{2} / \mathrm{R}^{2}$ & 0.186 & 0.089 & 0.108 \\
\hline
\end{tabular}


Note: All variables are defined in Model (1). Column (1) reports the results of estimating a probit regression, Column (2) reports the results of estimating an OLS regression, and Column (3) reports the results of estimating an ordered probit regression. Standard errors are robust and corrected for heteroscedasticity. *, **, and *** indicate significance levels at $10 \%, 5 \%$, and $1 \%$, respectively.

In Column (1) of Table 4, we find that inside director ownership (INS_SHARES) is significant and negatively associated with the likelihood of using NFPM (Z-stat $=-5.06, p<0.01)$, indicating that firms with higher inside director ownership are less likely to use NFPM to complement financial measures for CEO compensation. We do not find significant results for proportions of independent directors and $\mathrm{CEO} /$ Chairman duality for this portion of our analysis. However, board size, percentage of reputed directors, and percentage of female directors are associated with a higher likelihood of adopting NFPM $(\mathrm{Z}$-stat $=2.78, \mathrm{p}<0.01 ; \mathrm{t}$-stat $=3.61, \mathrm{p}<0.01 ; \mathrm{Z}$-stat $=5.26, \mathrm{p}<0.01)$, suggesting that large boards, reputable directors, and female directors favor the use of NFPM.

Focusing on the weights placed on NFPM (Column 2), we find that NFPM_WEIGHT is negatively associated with inside director ownership and positively related to percentage of female directors. In Column (3), the results are generally consistent those in Column (1), except that CEO/CHAIR is significant and positively associated with the number of NFPM. With respect to the control variables, Table 4 shows that larger firms and firms with better accounting performance are more likely to adopt NFPM, consistent with prior studies (e.g., Ittner et al., 1997; Said et al., 2003; HassabElnaby et al., 2005).

As discussed earlier, we further control the endogeneity problems originating from the nature of the board characteristics variables by using the instrumental variable approach and separately testing each independent variable. We tabulate those results in Table 5.

TABLE 5

INDIVIDUAL REGRESSION USING INSTRUMENTAL VARIABLE APPROACH

\begin{tabular}{lccc}
\hline & $(1)$ & $(2)$ & $(3)$ \\
& $\begin{array}{c}\text { P(NFPM_CODE) } \\
\text { Coefficient } \\
(Z)-s t a t)\end{array}$ & $\begin{array}{c}\text { NFPM_WEIGHT } \\
\text { Coefficient } \\
(\mathrm{t} \text {-stat) }\end{array}$ & $\begin{array}{c}\text { COUNTNFPM } \\
\text { Coefficient } \\
(\text { Z-stat })\end{array}$ \\
\hline INDPT_PCNT & $0.700^{* * *}$ & $0.032^{* *}$ & $0.554^{* * *}$ \\
& $(3.67)$ & $(2.51)$ & $(3.41)$ \\
INS_SHARES & $-0.105^{* * *}$ & $-0.005^{* * *}$ & $-0.072^{* * *}$ \\
& $(-6.25)$ & $(-4.05)$ & $(-5.09)$ \\
CEO/CHAIR & 0.440 & 0.012 & 0.960 \\
& $(0.52)$ & $(0.20)$ & $(1.22)$ \\
BOD_SIZE & $0.041^{* * *}$ & -0.000 & $0.030^{* * *}$ \\
& $(3.22)$ & $(-0.21)$ & $(2.96)$ \\
REPUTED_DIR & $0.846^{* * *}$ & -0.012 & $0.543 * * *$ \\
& $(4.05)$ & $(-0.77)$ & $(3.12)$ \\
FEMALE_PCNT & $1.848^{* * *}$ & $0.073 * * *$ & $1.592^{* * *}$ \\
Control Variables & $(6.18)$ & $(3.31)$ & $(6.96)$ \\
Industry fixed effect & Included & Included & Included \\
Year fixed effect & Yes & Yes & Yes \\
\hline
\end{tabular}

Note: This table summarizes the results of separately testing each independent variable of interest (proportion of independent directors, inside director ownership, board size, percentage of reputed directors, percentage of female directors, and $\mathrm{CEO} / \mathrm{Chairman}$ duality) using instrumental variables approach. The two instrumental variables used in the estimation are two-year lagged value of each board characteristic variable and one-year lagged free cash flow. The dependent variable, NFPM_CODE, is an indicator variable that takes the value of one if the firm uses NFPM in CEO compensation contracts, and zero otherwise; the dependent variable, NFPM_WEIGHT, is a continuous variable that suggests the weights placed on NFPM; the dependent variable, COUNTNFM, is a categorical variable measuring 
the number of NFPM used by a firm in a given year. All control variables are the same as those in Model (1). Column (1) reports the results of using the "ivprobit" Stata command to test the model with the instrumental variables; Column (2) reports the results of using the "ivregress" Stata command with two-stage least square option; and Column (3) reports the results of manually implementing two-stage regressions: in the first stage, OLS regression is employed by regressing individual independent variable of interest on its instrumental variables as well as the control variables in Model (1); predicted values are then generated from this stage and used as independent variables in the second stage. Standard errors are robust and corrected for heteroscedasticity. ${ }^{*}, * *$, and $* * *$ indicate significance levels at $10 \%, 5 \%$, and $1 \%$, respectively.

In Table 5, we find that proportion of independent directors is significant and positive for all three dependent variables $(Z$-stat $=3.67, \mathrm{p}<0.01$; t-stat $=2.51, \mathrm{p}<0.05$; Z-stat $=3.41, \mathrm{p}<0.01)$, suggesting that independent directors are more likely to use NFPM. Inside director ownership is significant and negatively associated with the likelihood of using NFPM, the weights placed on NFPM, and the number of NFPM (Z-stat $=-6.25, \mathrm{p}<0.01$; t-stat $=-4.05, \mathrm{p}<0.01 ; \mathrm{Z}$-stat $=-5.09, \mathrm{p}<0.01)$. These results imply that inside directors who have substantial financial interest in a firm, lack incentives to design a compensation scheme that is more forward looking and is aligned with the long-term perspective of shareholders. This supports the argument that an entrenched board can lead to decreasing board oversight, resulting in sup-optimal compensation design decisions (e.g., Morck et al., 1988; Shleifer \& Vishny, 1989). ${ }^{6}$ However, we do not find significant results when the independent variable of interest is $\mathrm{CEO}$ /Chairman duality. In addition, it shows that a larger board is associated with higher propensity for the use of NFPM and with the use of more types of NFPM, and that reputable directors (i.e., directors that sit on more than one BOD) favor the use of NFPM. However, this is not the case for the relation to the weights placed on NFPM. Lastly, the proportion of female directors is positively related to the use of NFPM, heavier weights, and more types NFPM (Z-stat $=6.18, \mathrm{p}<0.01$; t-stat $=3.31, \mathrm{p}<0.01$; Z-stat $=$ $6.96, \mathrm{p}<0.01)$.

\section{ADDITIONAL ANALYSES}

\section{Propensity Score Matching Sample}

Since each firm chooses whether to use (or refrain from using) NFPM in the design of CEO compensation, the results of our main analyses are subject to a possible confound, due to self-selection bias. To mitigate this issue, we use propensity score matching (PSM) and construct a one-to-one matched sample. ${ }^{7}$ By comparing firms using this technique, we can further account for factors that may have led to the decision to use NFPM. We include all control variables in the following propensity score selection logit model used to construct the PSM sample and make sure there are no significant differences between the treatment group (i.e., NFPM=1) and the control group (i.e. NFPM=0) in terms of all control variables:

$$
\begin{aligned}
& \mathrm{P}(\mathrm{NFPM} C \mathrm{CODE})=\beta_{0}+\beta_{1} \mathrm{SIZE}_{\mathrm{i}, \mathrm{t}-1}+\beta_{2} \mathrm{ROA}_{\mathrm{i}, \mathrm{t}-1}+\beta_{3} \mathrm{LEV}_{\mathrm{i}, \mathrm{t}-1}+\beta_{4} \mathrm{DIST}_{\mathrm{i}, \mathrm{t}-1 \text { thru }-5} \\
& +\beta_{5} \text { STRATEGY }_{\mathrm{i}, \mathrm{t}-1 \text { thru } \mathrm{t}-5}+\beta_{6} \text { MNOISE }_{\mathrm{i}, \mathrm{t}-1 \text { thru }-5}+\beta_{7} \mathrm{QUALITY}_{\mathrm{i}, \mathrm{t}} \\
& + \text { YEAR \& INDUSTRY }+\mathrm{e}_{\mathrm{i}, \mathrm{t}}
\end{aligned}
$$

Using the matched sample constructed based on the propensity score obtained from Model (2), we repeat our analysis using Model (1). The results are summarized in Table 6. Our findings are generally consistent with the main analyses. Using PSM, we document a negative association between board size and the use of NFPM and a positive association for the relation of reputable directors and female directors for the use of NFPM. Using the number of NFPM as the dependent variable (Column 3) our results are similar. In addition, we find that inside director ownership is negatively related to the weight placed on NFPM while female directors tend to place more weight on NFPM. 
TABLE 6

MULTIVARIATE REGRESSION FOR PSM SAMPLE

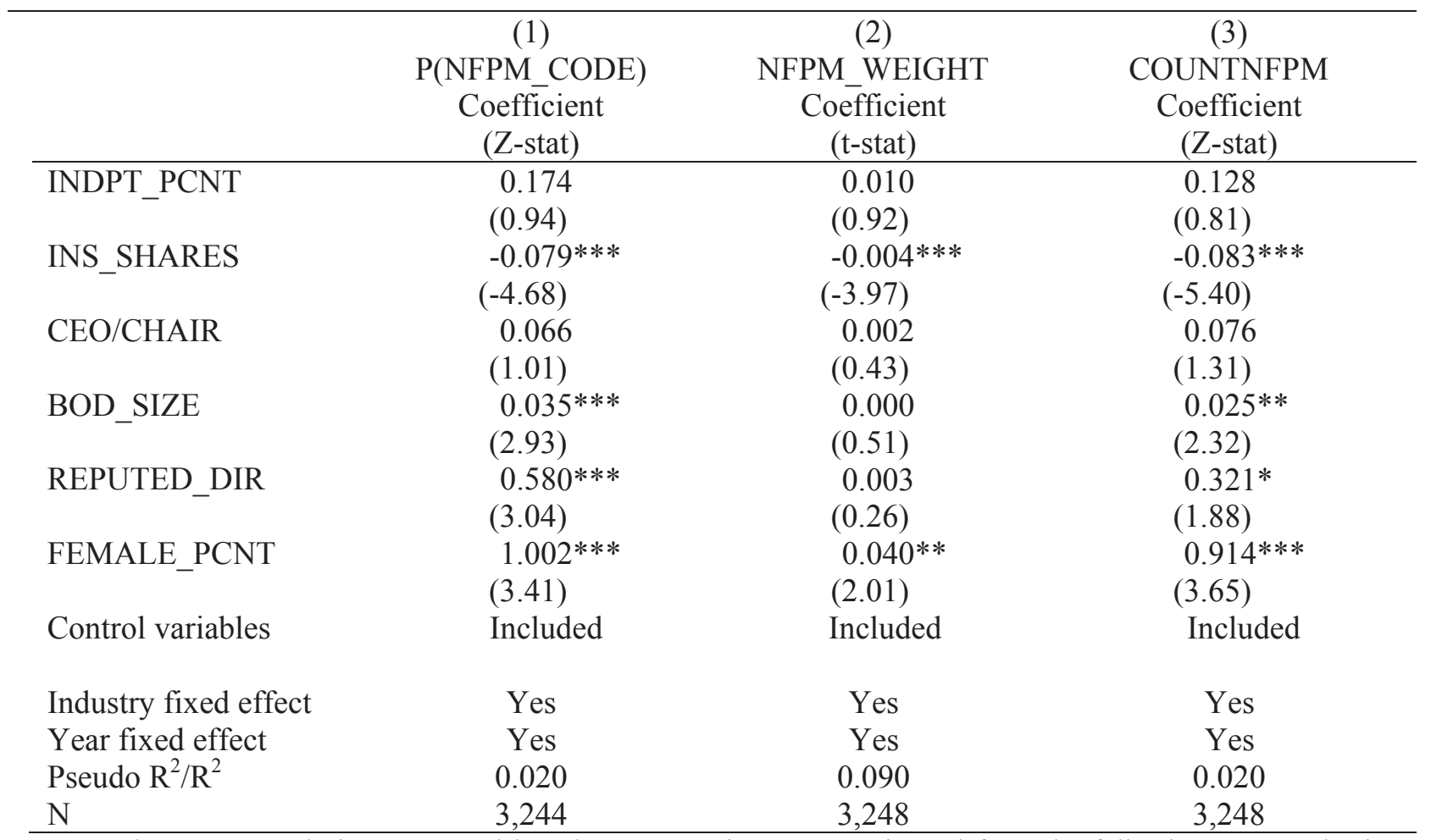

Note: The PSM sample is constructed based on propensity scores estimated from the following PSM selection model (with maximum caliper of 0.001 and without replacement one-to-one matching):

$$
\begin{aligned}
\text { P(NFPM_CODE })= & \beta 0+\beta 1 \text { SIZE }_{i, t-1}+\beta 2 \text { ROA }_{i, t-1}+\beta 3 \text { LEV }_{i, t-1}+\beta 4 \text { DIST }_{i, t-1 \text { thru } t-5} \\
& +\beta 5 \text { STRATEGY }_{i, t-1 \text { thru }-5}+\beta 6 \text { MNOISE }_{i, t-1 \text { thru }-5}+\beta 7 \text { QUALITY } \\
& + \text { YEAR }+{\text { INDUSTRY }+\mathrm{e}_{\mathrm{i}, \mathrm{t}}}
\end{aligned}
$$

All variables are defined in Model (1). Z-statistics are presented in parentheses below the coefficients and errors are robust and corrected for heteroskedasticity. $*, * *$, and $* * *$ indicate significance levels at $10 \%, 5 \%$, and $1 \%$, respectively.

\section{CONCLUSIONS}

In this study, we investigate whether the strength of corporate governance affects firms' choice of incorporating NFPM in CEO compensation contracts. The existing literature reports that NFPM contribute benefits that include: mitigating the noise in financial measures, providing more timely information about managerial behaviour and promoting better alignment of managerial actions to firm strategy, resulting in enhanced long-term performance (e.g., Lambert \& Larcker, 1987; Bruns \& McKinnon, 1993; Feltham \& Xie, 1994; Bushman et al., 1996; Kaplan \& Norton, 1996; Hemmer, 1996; Ittner et al., 1997; Ittner \& Larcker, 1998a; 1998b; 2003; Banker et al., 2000; Said et al., 2003; Davila \& Venkatachalam, 2004; HassabElnaby et al., 2005). However, NFPM are prone to managerial manipulation and less subject to public verification (e.g., Eccles \& Mavrinac, 1995; Ittner et al., 1997). Therefore, strong corporate governance may be essential to maximizing the utility of incorporating NFPM into CEO contracts. As such, we predict that the use of NFPM should be positively related to board characteristics indicative of strong board oversight in an optimal contracting environment. 
We find that several board characteristics, highlighted by prior research as being important to strong corporate governance, have a significant impact on the use of NFPM. These include board independence, inconsequential entrenchment, board size, director reputation and gender diversity. Specifically, we find evidence that board independence, board size, director reputation, and female directors are positively related to the use of NFPM. Alternatively, we find that in an environment where BOD monitoring is weakened by the increasing value of inside director ownership, firms are less likely to use NFPM. Together, these results suggest that the choice of whether to use NFPM in executive compensation is significantly influenced by the strength of a board.

Our research highlights the role that board composition and financial incentives play in the design of CEO compensation. We show that certain board characteristics enhance the BOD monitoring and advising capabilities. Additionally, our investigation provides evidence regarding the detrimental effects regarding high levels of equity incentives. If the BOD becomes entrenched, this can lead to a suboptimal contracting environment that does not promote shareholder interests. Given the complicated nature of CEO contracting and corporate governance, we suggest that future studies address how additional corporate governance characteristics, such as anti-takeover provisions, institutional ownership, and other factors, impact the choice of using NFPM.

\section{ENDNOTES}

1. Prior research indicates that the S\&P 500 is a credible indicator for firm behavior relating to the U.S. economy (Fama and French, 2002).

2. Following prior studies (Ittner et al., 1997; Said et al., 2003; HassabElnaby et al., 2005), firms that adopt any one of these terms are included as using NFPM and are coded as one.

3. For the dependent variable of NFPM_CODE, which indicates the likelihood of using NFPM, we use the "ivprobit" Stata command to test the model with the instrumental variables. For the dependent variable of NFPM_WEIGHT, which is a continuous variable, we use the "ivregress" Stata command with two-stage least square option. For the dependent variable of COUNTNFM, which is a categorical variable, we manually implement two-stage regressions: in the first stage, we employ OLS regression by regressing individual independent variable of interest on its instrumental variables as well as the control variables in Model (1); we then generate predicted values from this stage and employ them as independent variables in the second stage in which the dependent variable is COUNTNFM.

4. For example, to instrument for the percentage of independent directors for the year $t-1$, we use the percentage of independent board directors for year $\mathrm{t}-2$ and firm free cash flow for the year $\mathrm{t}-1$ as instruments.

5. The result of the F-test for the joint relevance of the two instrumental variables in the first stage was significant, providing evidence that the instruments are appropriate. Results of the tests for overidentifying restrictions using Sargan's (1958) and Basmann's (1960) test was not significant, indicating that the models are appropriately identified.

6. We conduct a Wald test for each of the models by testing whether the independent variables of interest and their respective instruments are simultaneously equal to zero. The significant p-values for the partial Chi2 (untabulated) suggest that our independent variables substantially improve the fit of Model (1).

7. We match, without replacement, a firm that does not use NFPM with a firm that employs NFPM and the closest predicted value from Model (2) within a maximum distance (caliper) of 0.05 percent. 


\section{REFERENCES}

Adams, R B., \& Ferreira, D. (2009). Women in the boardroom and their impact on governance and performance. Journal of Financial Economics, 94, 291-309.

Amir, E., \& Lev, B. (1996). Value-relevance of nonfinancial information: The wireless communications industry. Journal of Accounting and Economics, 22(1), 3-30.

Arun, G. T., Almahrog, Y. E., \& Aribi, Z. A. (2015). Female directors and earnings management: Evidence from the UK. International Review of Financial Analysis, 39, 137-146.

Banker, R. D., \& Mashruwala, R. (2007). The moderating role of competition in the relationship between nonfinancial measures and future financial performance. Contemporary Accounting Research, 24(3), 763-793.

Banker, R. D., Potter, G., \& Srinivasan, D. (2000). An empirical investigation of an incentive plan that includes nonfinancial performance measures. The Accounting Review, 75(1), 65-92.

Basmann, R. L. (1960). On finite sample distributions of generalized classical linear identifiability test statistics. Journal of the American Statistical Association, 55(292), 650-659.

Baysinger, B. D., \& Butler, H. N. (1985). Corporate governance and the board of directors: performance effects of changes in board composition. Journal of Law, Economics, and Organization, 1(1), 101-124.

Baysinger, B. D., \& Hoskisson, R. E. (1990). The composition of boards of directors and strategic control: Effects on corporate strategy. Academy of Management Review, 15, 72-87.

Beasley, M. S. (1996). An empirical analysis of the relation between the board of director composition and financial statement fraud. The Accounting Review, 71(4), 443-465.

Boyd, B. K. (1994). Board control and CEO compensation. Strategic Management Journal, 15, 335-344.

Bruns, Jr. W. J., \& McKinnon S. M. (1993). Information and managers: A field study. Journal of Management Accounting Research, 5, 84-108.

Bushman, R. M., Indjejikian, R. J., \& Smith, A. (1996). CEO compensation: The role of individual performance evaluation. Journal of Accounting and Economics, 21(2), 161-193.

Core, J. E., Holthausen, R. W., \& Larcker, D. F. (1999). Corporate governance, chief executive officer compensation, and firm performance. Journal of Financial Economics, 51, 371-406.

Cyert, R. M., Kang, S., \& Kumar, P. (2002). Corporate governance, takeovers, and top-management compensation: theory and evidence. Management Science, 48(4), 453-469.

Davila, A., \& Venkatachalam, M. (2004). The relevance of non-financial performance measures for CEO compensation: Evidence from the airline industry. Review of Accounting Studies, 9(4), 443-464.

Eccles, R., \& Mavrinac, S. (1995). Improving the corporate disclosure process. Sloan Management Review, 36(Summer), 11-25.

Faccio, M., Marchica, M. T., \& Mura, R. (2016). CEO gender and corporate risk-taking. Journal of Corporate Finance, 39(August), 193-209.

Fama, E. F., \& French, K. R. (2002). The equity premium. The Journal of Finance, 57(2), 637-659.

Fama, E. F., \& Jensen, M. C. (1983). Separation of ownership and control. Journal of Law and Economics, 26(2), 301-325.

Feltham, G. A., \& Xie, J. (1994). Performance measure congruity and diversity in multi-task principal, agent relations. The Accounting Review, 69(3), 429-453.

Fich, E. M., \& Shivdasani, A. (2007). Financial fraud, director reputation, and shareholder wealth. Journal of Financial Economics, 86, 306-336.

Guest, P. (2009). The impact of board size on firm performance: Evidence from the UK. The European Journal of Finance, 15(4), 385-404.

Gul, F. A., Srinidhi, B., \& Ng, A. C. (2011). Does board gender diversity improve the informativeness of stock prices? Journal of Accounting and Economics, 51(3), 314-338.

HassabElnaby, H. R., Said, A. A., \& Wier, B. (2005). The retention of nonfinancial performance measures in compensation contracts. Journal of Management Accounting Research, 17(1), $23-$ 42. 
Hauser, J. R., Simester, D. I., \& Wernerfelt, B. (1994). Customer satisfaction incentives. Marketing Science, 13(4), 327-350.

Haveman, H. A. (1993). Organisational size and change: Diversification in the savings and loan industry after deregulation. Administrative Science Quarterly, 38, 20-50.

Hemmer, T. (1996). On the design and choice of "modern" management accounting measures. Journal of Management Accounting Research, 8, 87-116.

Hermalin, B. E., \& Weisbach, M. S. (1991). The effects of board composition and direct incentives on firm performance. Financial Management, 20(4), 101-112.

Holmstrom, B. (1979). Moral hazard and observability. The Bell Journal of Economics, 10(1), 74-91.

Ittner, C. D., \& Larcker, D. F. (1998a). Are nonfinancial measures leading indicators of financial performance? An analysis of customer satisfaction. Journal of Accounting Research, 36, 1-35.

Ittner, C. D., \& Larcker, D. F. (1998b). Innovations in performance measurement: trends and research implications. Journal of Management Accounting Research, 10, 205-238.

Ittner, C. D., \& Larcker, D. F. (2003). Coming up short on nonfinancial performance measurement. Harvard Business Review, 81(11), 88-95.

Ittner, C. D., Larcker, D. F., \& Rajan, M. V. (1997). The choice of performance measures in annual bonus contracts. The Accounting Review, 72(2), 231-255.

Jensen, M. C. (1993). The modern industrial revolution, exit, and the failure of internal control systems. Journal of Finance, 48, 831-880.

Jensen, M.C., \& Meckling, W. H. (1976). Theory of the firm: Managerial behavior, agency costs and ownership structure. Journal of Financial Economics, 3(4), 305-360.

Kaplan, R. S. (1982). Advanced Management Accounting, Englewood Cliffs, New Jersey.

Kaplan, R. S., \& Atkinson, A. A. (1998) Advanced Management Accounting. Upper Saddle River, New Jersey.

Kaplan, R. S., Johnson, H. T. (1987) Relevance Lost: The Rise and Fall of Management Accounting, Boston, Massachusetts.

Kaplan, R. S., Norton, D. P. (1996). Using the balanced scorecard as a strategic management system. Harvard Business Review, 74(1), 75-85.

Lambert, R. A., \& Larcker, D. F. (1987). An analysis of the use of accounting and market measures of performance in executive compensation contracts. Journal of Accounting Research, 25, 85-125.

Lambert, R. A., Larcker, D. F., \& Weigelt, K. (1993). The structure of organizational incentives. administrative science quarterly, 38(3), 438-461.

McConnell, J. J., \& Servaes, H. (1990). Additional evidence on equity ownership and corporate value. Journal of Financial Economics, 27, 595-612.

Mehran, H. (1995). Executive compensation structure, ownership, and firm performance. Journal of Financial Economics, 38, 163-184.

Mizruchi, M. S. (1983). Who controls whom? An examination of the relation between management and boards of directors in large corporations. Academy of Management Review, 8, 426-435.

Morck, R., Shleifer, A., \& Vishny, R. W. (1988). Management ownership and market valuation: an empirical analysis. Journal of Financial Economics, 20, 293-315.

Nagar, V., \& Rajan, M. V. (2001). The revenue implications of financial and operational measures of product quality. The Accounting Review, 76(4), 495-513.

O'Connell, V., \& O'Sullivan, D. (2014). The influence of lead indicator strength on the use of nonfinancial measures in performance management: Evidence from CEO compensation schemes. Strategic Management Journal, 35(6), 826-844.

Ohlson, J. A. (1980). Financial ratios and the probabilistic prediction of bankruptcy. Journal of Accounting Research, 18(1), 109-131.

Ryan, H. E., \& Wiggins, R. A. (2001). The influence of firm- and manager-specific characteristics on the structure of executive compensation. Journal of Corporate Finance, 7(2), 101-123. 
Said, A. A., HassabElnaby, H. R., \& Wier, B. (2003). An empirical investigation of the performance consequences of nonfinancial measures. Journal of Management Accounting Research, 15(1), 193-223.

Sargan, J. D. (1958). The estimation of economic relationships using instrumental variables. Econometrica, 26, 393-415.

Schiehll, E., \& Bellavance, F. (2009). Boards of directors, CEO ownership, and the use of non-financial performance measures in the CEO bonus plan. Corporate Governance: An International Review, $17(1), 90-106$.

Sedatole, K. L. (2003). The effect of measurement alternatives on a nonfinancial quality measure's forward-looking properties. The Accounting Review, 78(2), 555-580.

Shleifer, A., \& Vishny, R. W. (1989). Management entrenchment: The case of manager-specific investments. Journal of Financial Economics, 25, 123-139.

Srinidhi, B., Gul, F. A., \& Tsui, J. (2011). Female directors and earnings quality. Contemporary Accounting Research, 28(5), 1610-1644.

Srinivasan, D., Sayrak, A., \& Nagarajan, N. J. (2004). Executive compensation and non-financial performance measures: A study of the incentive relevance of mandated non-financial disclosures in the U.S. airline industry. Review of Accounting Studies, 9(4), 443-464.

Weisbach, M. S. (1988). Outside directors and CEO turnover. Journal of Financial Economics, 20, 431460.

Yermack, D. (1996). Higher market valuation of companies with a small board of directors. Journal of Financial Economics, 40, 185-211. 